\title{
Change in the Basic Structure of the Rabies Virus Glycoprotein by Reverse Genetics
}

\author{
Narges Miandehi ${ }^{1}$, Seyed Kazem Bidoki ${ }^{1}$, Mehdi Ajorloo ${ }^{2}$, Alireza Gholami ${ }^{* 3}$ \\ 1. Department of Biology, Payam-e Noor University, Tehran, Iran \\ 2. Department of Clinical Laboratory Sciences, School of Allied Medicine, Lorestan University of Medical Sciences, Khorramabad, Iran \\ 3. Human Rabies Vaccine Department, Research Production Complex, Pasteur Institute of Iran, Tehran, Iran
}

\section{ABSTRACT}

Background: Rabies is a deadly zoonotic disease that is caused by the rabies virus. The virus can infect and disrupt the central nervous system of a rabid patient. The rabies virus is a neurotropic single stranded RNA virus. Glycoprotein (G) is the most important protein that binds to the cellular receptors and also induces an immune response against the virus in the host. Using reverse genetics technology, the glycoprotein gene could be modified and a virus with higher immunogenicity or lower pathogenicity.

Materials \& Methods: In this study, we designed a mutation in the sequence of glycoprotein gene using a software, on the main antigenic site II of the Pasteur virus strain at the position of 42-34 amino acids. Agene fragment in the cloning vector containing the rabies virus genome was replaced by the synthesized construct containing the altered gene by two restricted enzymes, and then cloned. The T7-BHK cell under the T7 phage promoter control was transfected to express the glycoprotein gene, along with the construct and vectors expressing the $N, P$, and $L$ genes of the rabies virus as well as the full genome. After expressing and confirming viral genes, it was cultured and amplified in BSR cell.

Results: after cloning and expression of the recombinant virus in the target cell, the vector containing the mutated gene led to the rescue of the recombinant virus. The recombinant virus cultured and propagated in the BSR cells, then the genome was extracted and finally confirmed by sequencing.

Conclusion: The rescued recombinant virus can be used for research studies or in the vaccines manufacturing, provide that the antigenicity is maintained or increased.

Keywords: Rabies, Reverse genetics, Vaccine, Glycoprotein, Recombinant virus

\begin{tabular}{|c|c|c|c|c|}
\hline \multicolumn{3}{|c|}{ Received: 2020/04/05; } & Accepted: 2020/06/02; & Published Online: $2020 / 07 / 20$ \\
\hline \multicolumn{2}{|c|}{ Corresponding Information: } & \multicolumn{3}{|c|}{$\begin{array}{l}\text { Alireza Gholami, Human Rabies Vaccine Department, Research Production Complex, Pasteur Institute of Iran, Tehran, Iran. } \\
\text { Email: a.gholami@ pasteur.ac.ir }\end{array}$} \\
\hline (c) (1) (1) & \multicolumn{4}{|c|}{$\begin{array}{l}\text { Copyright (c) 2020, This is an original open-access article distributed under the terms of the Creative Commons Attribution-noncommercial } 4.0 \text { International License whicl } \\
\text { permits copy and redistribution of the material just in noncommercial usages with proper citation. }\end{array}$} \\
\hline
\end{tabular}

Use your device to scan and read the article online

Miandehi N, bidoki K, Ajorloo M, Gholami A. Change in the Basic Structure of the Rabies Virus Glycoprotein by Reverse Genetics. Iran J Med Microbiol. 2020; 14 (4) :348-360

\section{Download citation: BibTeX | RIS | EndNote | Medlars | ProCite | Reference Manager | RefWorks} Send citation to: $\Theta_{\text {Mendeley }} \mathbf{z}$ zotero ${ }_{\text {RefWorks }}$

\section{Introduction}

Rabies is a deadly zoonotic disease caused by rabies virus, spread around the world and can infect all mammals, including humans. The virus infects the central nervous system and leads to disorders in central nervous system (1), with horrible and acute neurological symptoms in the clinical stage. The rabies virus belongs to the rhabdovirus family and lyssavirus genus. Their genetic material is a single-stranded RNA with a negative polarity and a length of about $12 \mathrm{~kb}$. The genome of virus encodes five proteins (N, P, M, G, and L) (2). The $G$ protein (glycoprotein) binds to some specific cell's receptors and also provokes immune response against the virus in the host. Antigenic sites on $G$ protein are essential roles in this regard. The antigenic site I carries linear and three-dimensional epitopes located between226-231 amino acid residues. 
Another major antigenic site II is located between the amino acids 34-42 (II_b) and 198-200 (II_a). The main antigenic site III is a continuous epitope located between the amino acids 330-338.Epitope IV consists of only one amino acid at position 251. The G1 (also called the antigenic site a) and G5 sub-antigenic sites are also in positions 342-343 and 261-264, respectively (3) (Figure 1).

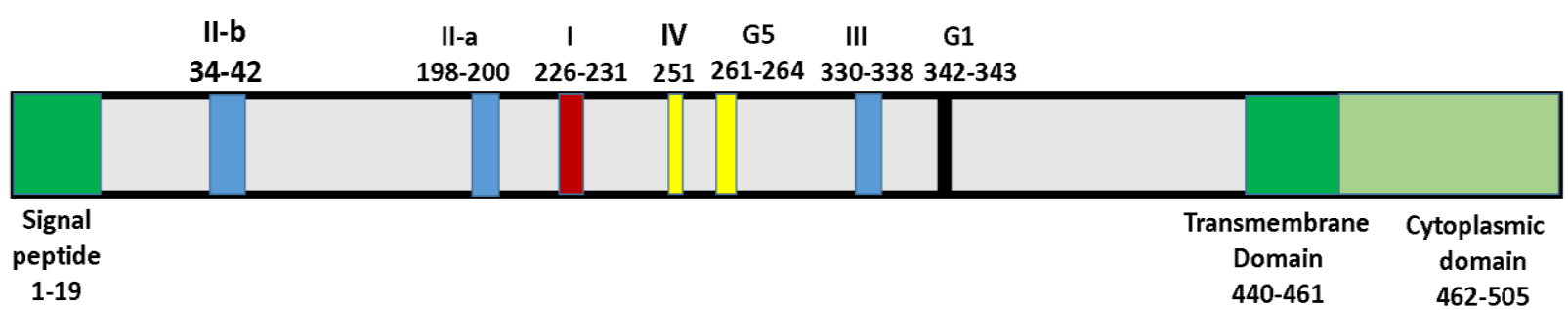

Figure 1. Schematic view of the glycoprotein structure of rabies virus. The main antigenic sites and the location of the amino acids associated with them.

The virus enters the cell via the endocytic pathway, and its replication and propagation cycle is entirely cytoplasmic (5). Once the virus genome is released into the cytoplasm, its genome is used as mRNA to express viral proteins genes, as well as to synthesisantigenome (positive polarity) in order to amplify the virus genome. The rabies virus polymerase complex is consisted of phosphoprotein and the polymerase protein ( $\mathrm{P}$ and $\mathrm{L}$ respectively), which is responsible for transcription and replication of the virus genome (6). According to the above, in the construction of the recombinant rabies virus with reverse genetic technology, only $N, P$, and $L$ proteins are necessary to form the virus-producing devices. Reverse genetics is a type of technology that manipulates and makes genetic changes in an organism in order to study the altered phenotype in the organism (7).In order to rescue a recombinant and active RNA virus, the cDNA clone from the virus should be prepared and converted into an RNA molecule inside the host cell (9).Genetic modification of the rabies virus toward improving its immunogenicity is one of the valuable applications of this technology. Accordingly, with the aim of establishing a suitable basis for this method in the country and using it in future research, genetic modification in the glycoprotein of rabies virus was done and its release of the active virus particle from the cell was shown.

\section{Materials and Methods}

\section{Design and Manufacture of Mutated Glycoprotein}

The genetic sequence of the rabies virus glycoprotein strain of Pasteur virus (PV) was obtained from the NCBI database. To generate the desired genetic mutation, the Mega4 software was used to change the genetic code from glycine (GGG) to glutamic acid (GAG) at the main antigenic site II_b, amino acid number 40.
Insertion of Mutated Glycoprotein into the Expression Vector

The mutated glycoprotein-carrying plasmid of the rabies virus was cut by the two restricted enzymes Nco I and SnaB I (Thermo Fisher) and the glycoprotein gene was removed and replaced in the expressing construct of the rabies virus (PV strain) genome instead of the original gene. After cloning in the Top 10 bacteria, PCR was performed and send to gene sequencing.

\section{Animal Cell Culture}

After transfection of the T7-BHK cell with expression vectors of $N, P, L$ and modified $G$ genes by lipofectamin 2000 (Invitrogen), the recombinant virus was rescued and inoculated to the BSR (Baby Syrian Related) cells.

\section{Confirmation of Mutant Virus Sequence After Recovery}

In order to compare the sequence of the mutated virus with other samples studied in this study, the cells of which were collected and RNA extraction was performed. cDNA was made from extracted RNA. The glycoprotein gene was then multiplied using PCR and specific primers and the PCR product was sent for sequencing.

\section{Results}

\section{Confirmation of the Mutated Glycoprotein Gene Sequence in the Expression Vector}

Mutated glycoprotein gene was transferred into the construct expressing the genome of the rabies virus by two restriction enzymes. The new cloned gene was generated by suitable PCR primers (Figure 2). 


\section{Transfected T7-BHK Cell by Expression Plasmids Containing Virus Genes}

The expression genes are depended on the T7-RNA polymerase promoter, produced in this cells. To ensure the correct function of the cells in polymerase expression, the cells were transfected with 4T7A construct and their presence of eGFP protein in microscopic evaluation was well confirmed (Figure 3).Transfection of the above cells with full genomes and expression constructs of virus ( $N, P$, and $L$ ) confirmed the expression of viral proteins in T7-BHK cells after specific staining (Figure 4).
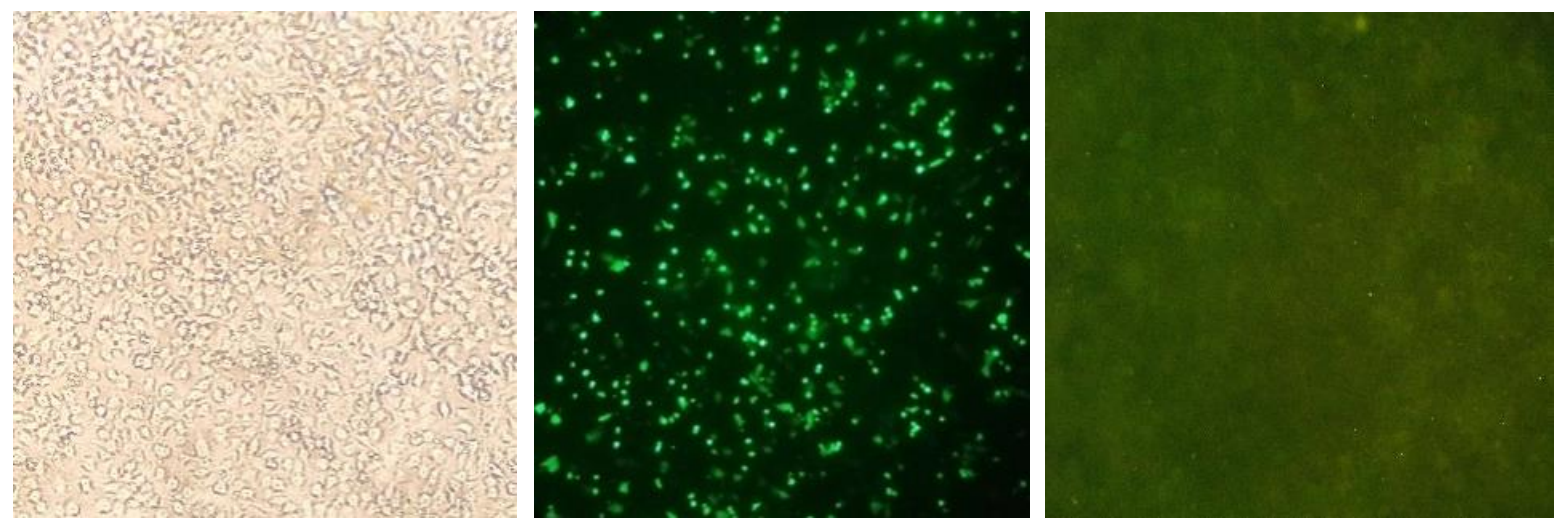

Figure 3. T7-BHK cells transfection results. T7-BHK cells (right), T7-BHK cells transfected with 4T7A structure to confirm T7 polymerase function (middle), the negative control cells with immunofluorescence staining (left).
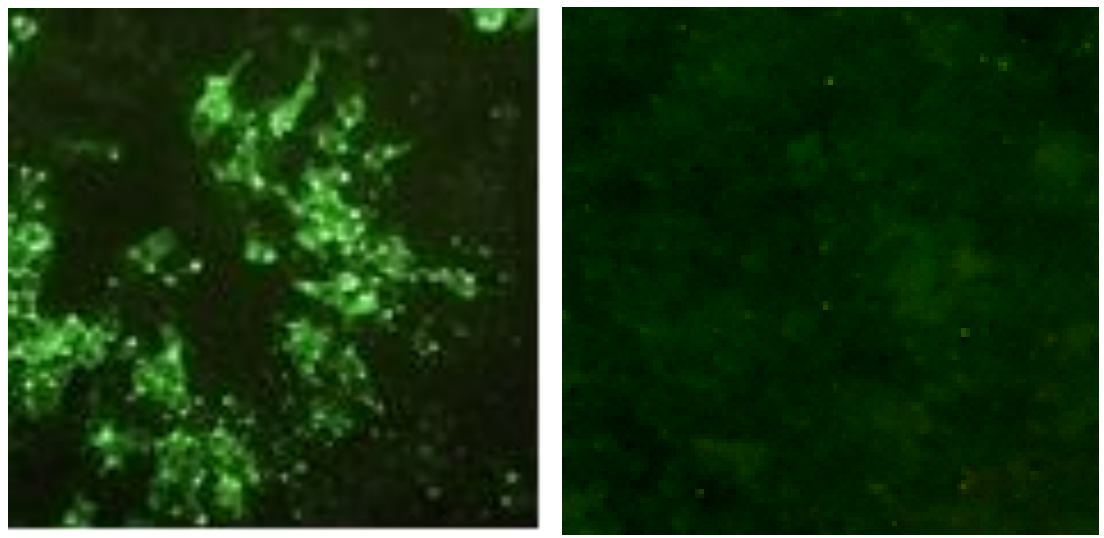

Figure 4. T7BHK cell transfected with expression plasmids. The cell containing the virus genome, with the expression vectors containing the L, P, and $\mathrm{N}$ genes of immunofluorescence staining with specific antibodies, shows the production of viral proteins (left). Negative control cells transfected with the same plasmids except L (right). 


\section{Infectivity of Recovered Viruses in the BSR Cells}

Microscopic observation of BSR cells after specific staining confirmed the ability of virus to infect the cells. It was also observed that the infectivity of the recovered virus improved during subsequent passages (Figure 5). RNA extraction was performed from the virus produced in the BSR cell and sequencing of the virus glycoprotein gene confirmed the presence of a mutation in the recovered virus (Figure 6).
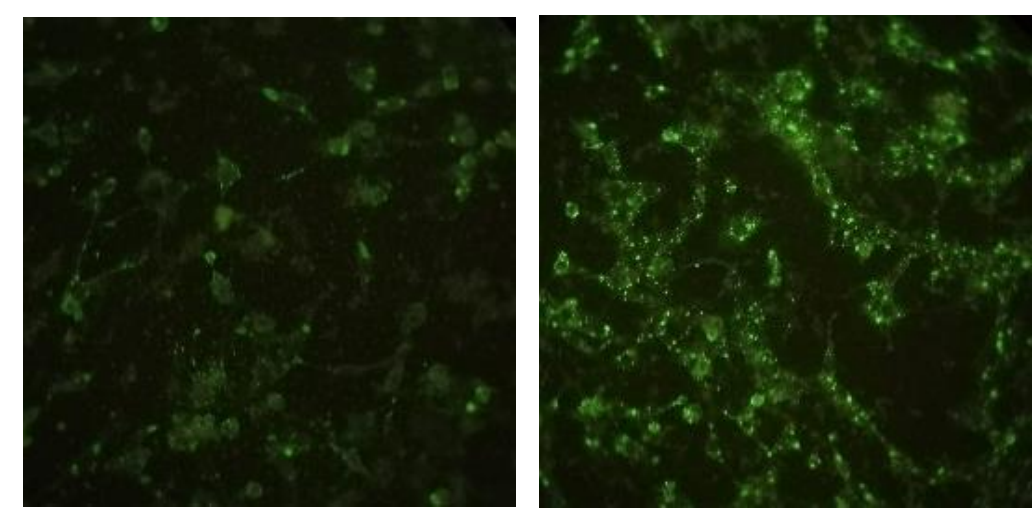

Figure 5. Increasing the virus's ability to infect during consecutive cultures: The left side of the virus-infected cells in the first passage of the virus, compared to the cells infected in the second passage of the virus (right).

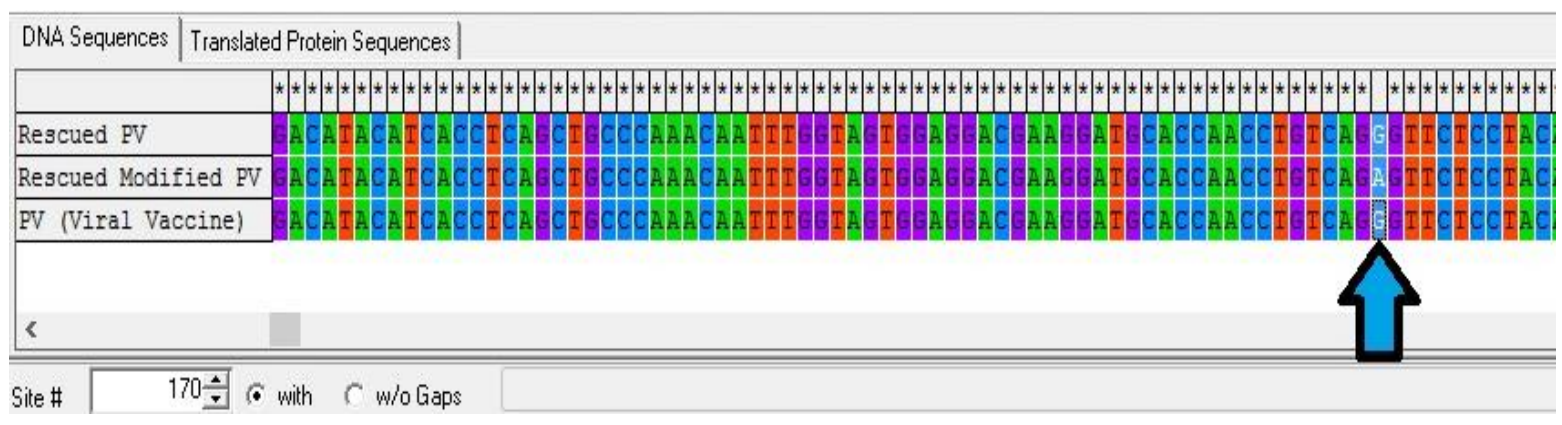

Figure 6. Determination of glycoprotein sequence of non-mutated recovered virus (Rescued PV), control vaccine strain (PV) virus, mutated recovered virus (Rescued Modified PV). The location of the mutated nucleotide is shown in the figure with the arrow.

\section{Discussion}

In this study, using genetic engineering methods, molecular changes were created in the glycoprotein of rabies virus and the recombinant virus recovered. The virus has shown the ability to infect animal cell culture. In 2003, Nauto Ito et al. improved the recovery of rabies virus from cloned cDNA using reverse genetics without the vaccinia auxiliary virus (18). In the present study, the recombinant rabies virus was recovered using a similar system, the desired change in glycoprotein gene was first altered and then transfected to T7-BHK cell with others viral proteins encoding genes. Rabies virus glycoprotein (RVGP) is the main antigen of the virus and is the only viral component of all new rabies vaccines available. Many new methods have been used since recombinant DNA technology became available for the expression of recombinant immunogenic viral glycoproteins (rRVGP). Recent studies on the development of rabies vaccines have focused on the expression of rRVGP in vivo by transferring the viral vectors into the body. This method is considered as the basis of biotechnology for the new generation of rabies vaccines (27).

\section{Conclusion}

In this study, we tried to rescue the rabies virus by modifying the structure of the protein that is effective in the antigenicity and immunogenicity, so that it could be used in qualitative and quantitative tests required for rabies vaccine

\section{Acknowledgment}

This work was supported by the production and research complex of Pasteur Institute of Iran. Human rabies vaccine production department.

\section{Conflict of Interest}


Authors declared no conflict of interests. 


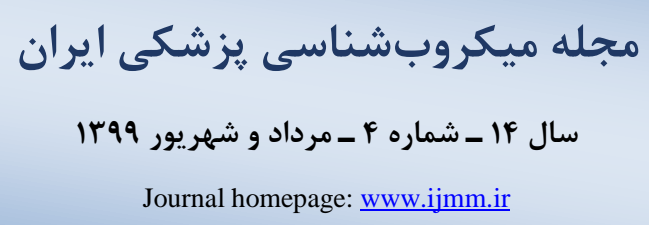

ايجاد تغيير در ساختار اوليه كليكويروتئين ويروس هارى و جايكزين كردن آن در ساختار ويروس هارى با روش زنتيك معكوس

نر كس مياندهى'، سيد كاظم بيدكى'، مهدى آجورلو'، عليرضا غلامى

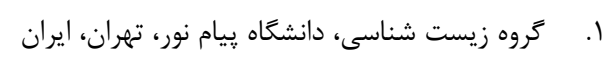

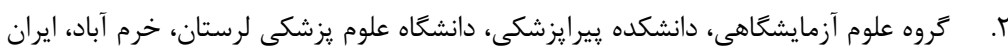

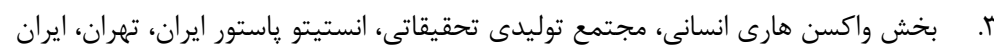

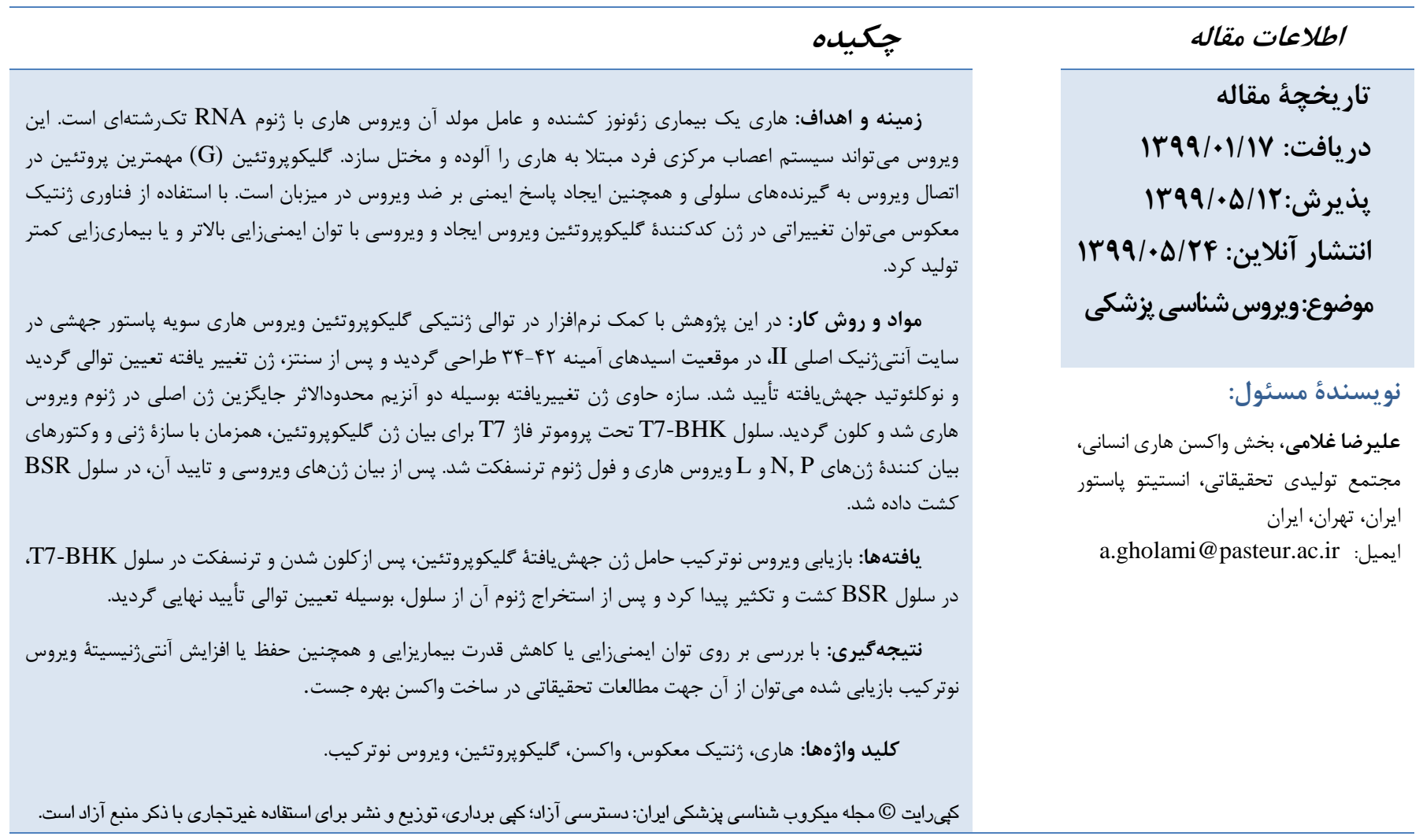

مقلمها

مشتمل بر أlf زنوتيب مىشود. زنوتيب I شامل ويروس هارى

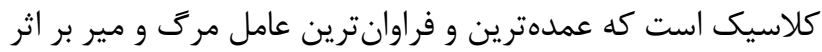

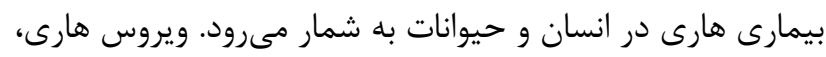

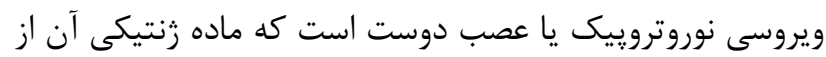

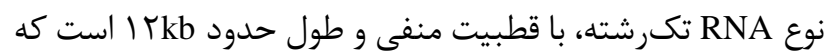

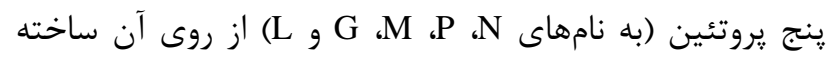

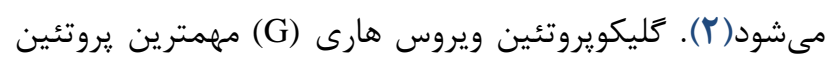

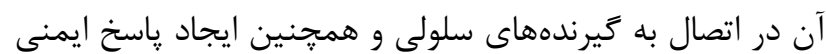

هارى يك بيمارى زئونوز كشنده است كه غالباً جوامع محروم را هدف قرار مىدهد. عامل مولد بيمارى هارى ويروس هارى است

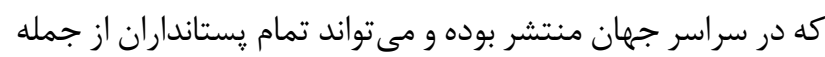
انسان را مبتلا كند. اين ويروس سيستم عصبى مركزى راس رآ آلوده كرده و منجر به اختلال در سيستم اعصاب مركزى مىشود (1) كه در مرحله بالينى با نشانهاى هولناك و بروز علائم حاد عصبى در درد

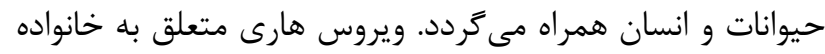

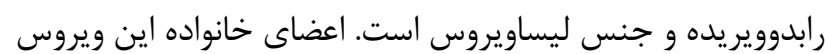


قرار دارد. ايىتوت IV تنها از يك اسيدآمينه در موقعيت IVIV تشكيل شده است. سايتهاى آنتىزنيك فرعى G1 (يا a) و G5 نيز

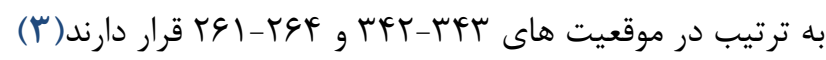
(شكل (). اسيدآمينه شماره سبس به تنهايى در بيمارىزايى ويروس هوس

$$
\text { نقش كليدى ايفا مى كند (F). (F). }
$$

بر ضد ويروس در ميزبان است. سايتهاى آنتىزنيك بر روى اين

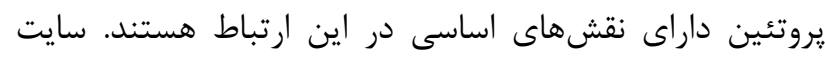

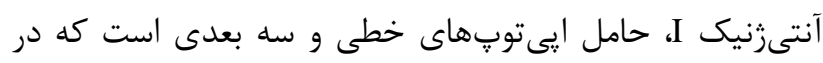

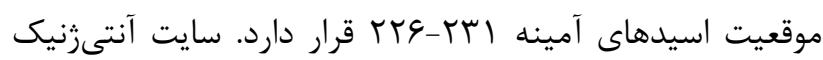

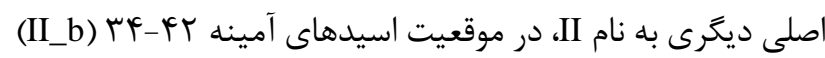

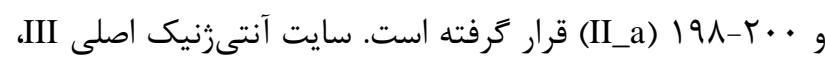

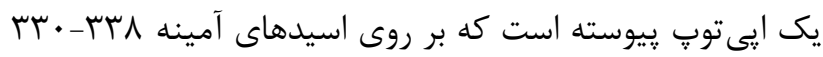

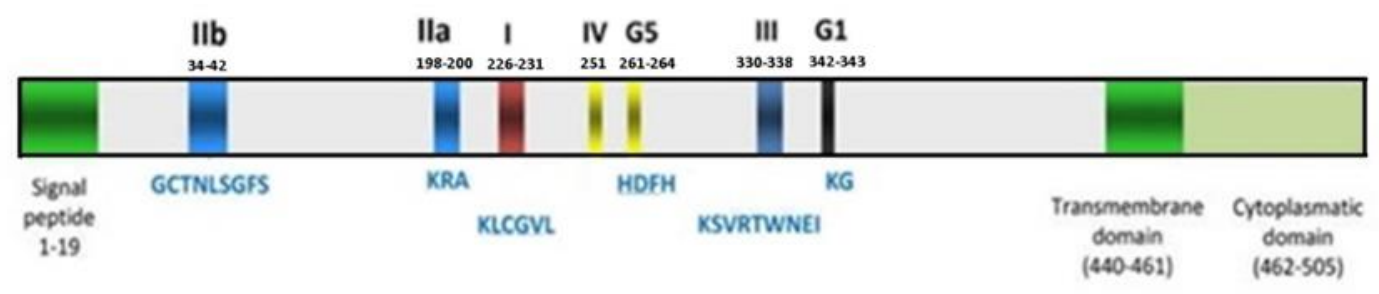

شكل ا. نماى شماتيك از كليكويروتئين و جايكاههاى آنتىزنيك ويروس هارى.

دار نوتركيب و فعال بايد كلون cDNA حاصل از ويروس تهيه و در

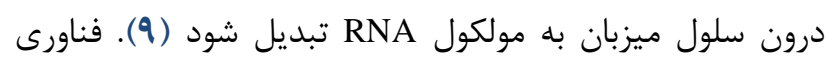
زنتيك معكوس براى نخستين بار در سال I9 19 براى ساخت

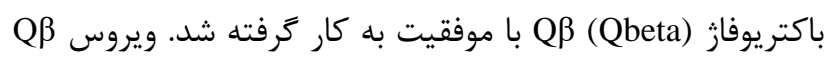

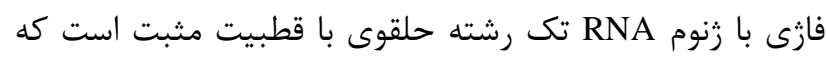

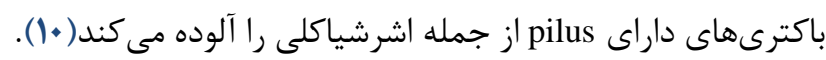
اين فناورى سيس حدود يك دهه بعد با استفاده از سيستم

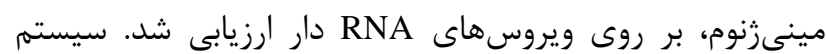
مينىزنوم بر اساس رونويسى از توالىهاى انتهايى يك قطعه از زنوم

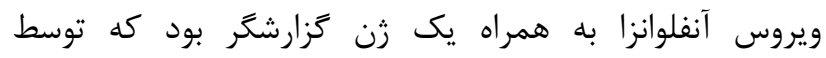

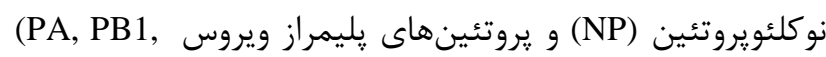

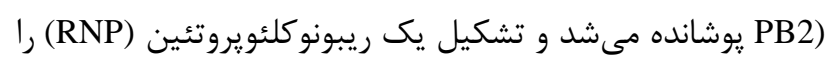
مىداد. ترانسفكت كردن سلول با اين RNP نوتركيب به همراه

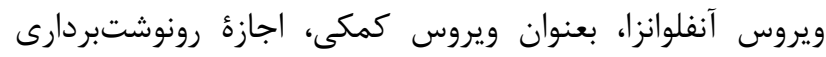
وترجمه از زن گزارشگر را مىداد، به اين ترتيب كه ويروس كمكى ويرى

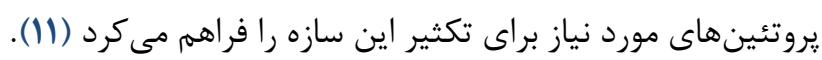

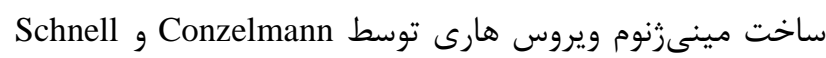

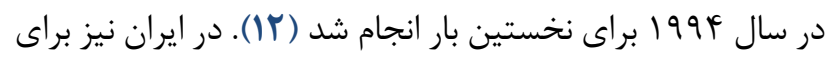
نخستين بار در سال 91 • ب ساخت مينىزنوم ويروس هارى توسط آجورلو و همكارانش انجام شد (سا). در تمام اين سيستممها يروتئينهاى مورد نياز براى كيسيده كردن، رونوشت بردارى و تكثير

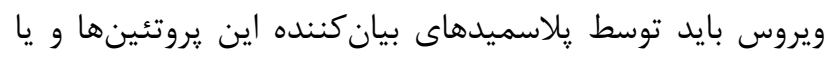

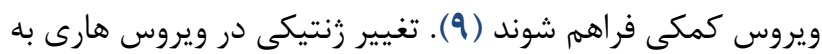
منظور بهبود توان ايمنىزايى آن، يكى از كاربردهاى ارزشمند اين
اين ويروس از طريق مسير آندوسيتوزى وارد سلول مىشود

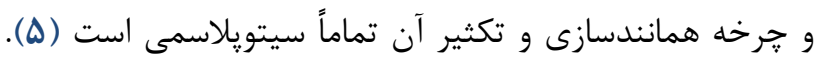
زنوم ويروس يس از آزاد شدن در سيتويلاسم، الكوى ساخت براى بيان زنهاى ويروسى و همجنين ساخت آنتىزنوم

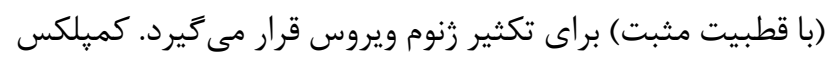
P) يليمرازى ويروس هارى شامل فسفويروتيين و يروتئين : يليمراز و است كه وظايف نسخهبردارى و همانندسازى را عهدهدار هستند. در اين فرايندها حضور نوكلئويروتئين ويروس (N) نيز نقش حساس و حياتى دارد. در مجموع، اين سه يروتئين به همراه زنوم ويروس براى تكثير ينج يروتئين ويروس و همانندسازى آن دئن در سلول ميزبان ضرورى هستند (و). بر همين اساس است كه در ساخت ويروس هارى نوتركيب با فناورى زنتيك معكوس، فقط به يروتئينهاى N، P و أبعنوان دستخاه سازنده ويروس نياز است. زنتيك معكوس نوعى فناورى است كه با دستكارى و ايجاد تغييرات

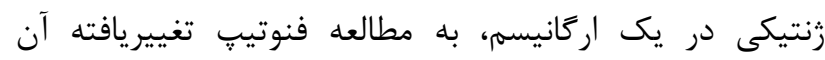
ار Fانيسهم براساس تغييرات زنتيكى ايجاد شده مى يردازد. يكى از جنبdهاى مهرم و كاربردى اين فناورى، ساخت ويروسهاى نوتركيب بهينهسازى شده جهت ساخت واكسن، با كاهش دادن يا

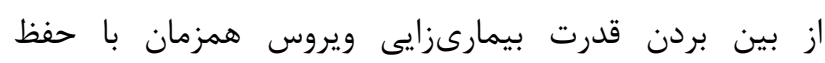

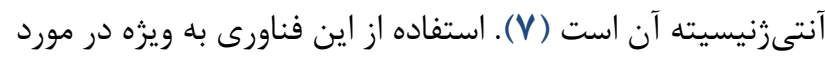
ويروسهاى RNA دار با قطبيت مثبت، به دليل سهولت دستكارى

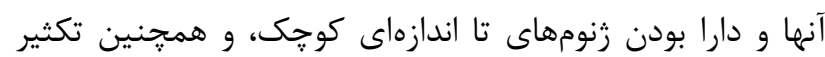

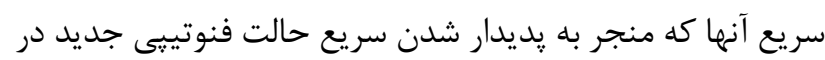

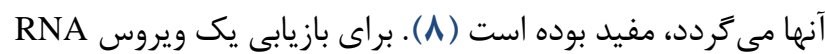


استفاده شد و كرمخانهَذارى در دماى Vآ درجه سلسيوس (FBS)

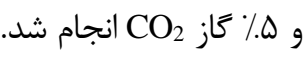

\section{انتقال DNA به درون سلول با روش لييوفكشن}

وكتورهاى بيان كنندة زنهاى N، P و L ويروس هارى در يزوهشهاى بيشين تهيه شده بود و براى ساخت ويروس هارى جهش يافته در اختيار اين كار قرار داده شد (بار). اين وكتورها

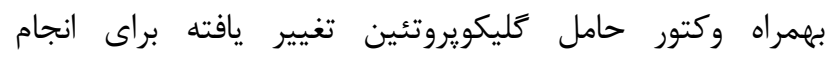
ترانسفكن مورد استفاده قرار كرفتند. براى اطمينان از صحت

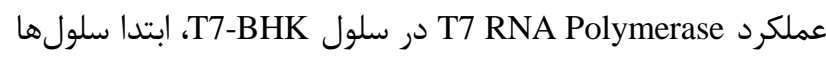
با سازه 4T7A (IF) ترانسفكت شد كه بيان كننده يروتئين

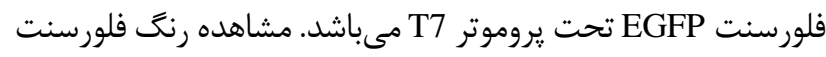

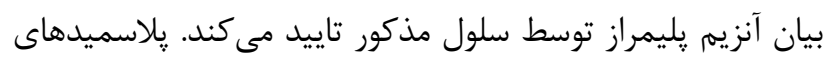

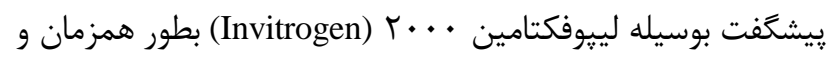

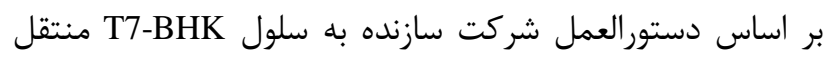

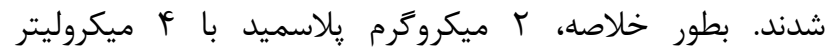

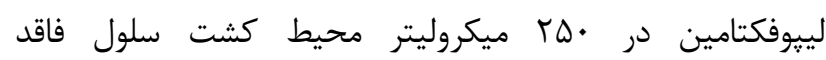

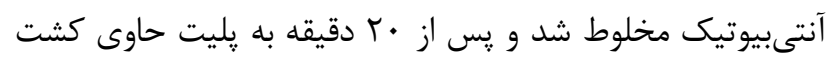

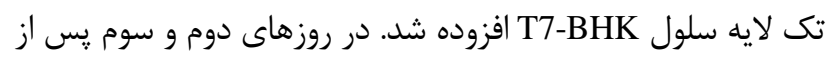

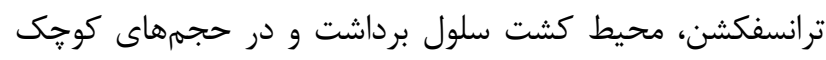

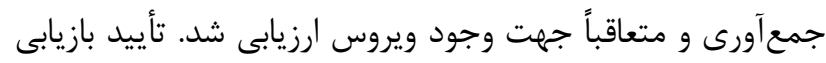

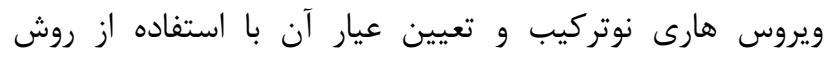

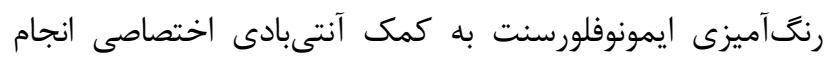

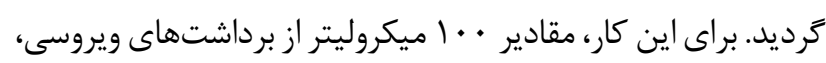

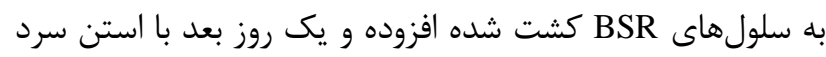

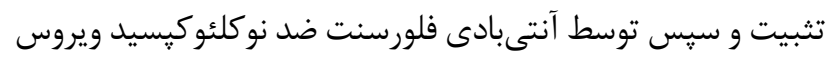

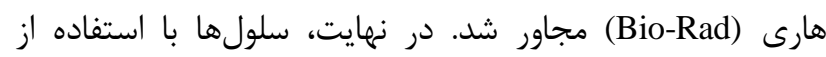

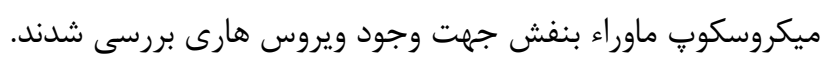

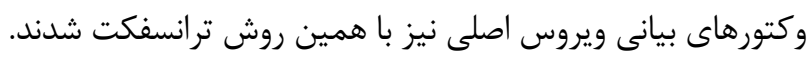

\section{تلقيح كشت سلول جانورى با ويروس نوتركيب}

براى بررسى قابليت آلودهكندگى هر سه نوع ويروس مورد

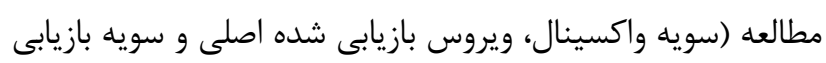
شده جهش يافته) بطور جداكانه به سلولهاى BSR تلقيح شدند.

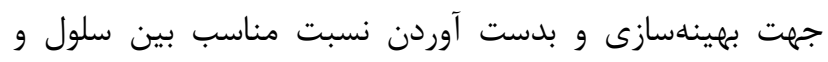

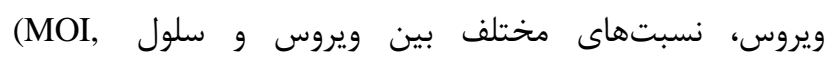
Multiplicity of Infection)
فناورى است. بر همين اساس و با هدف ايجاد بنيان مناسب براى

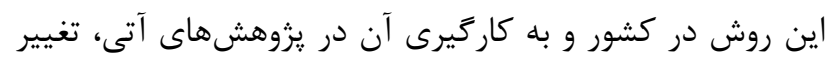

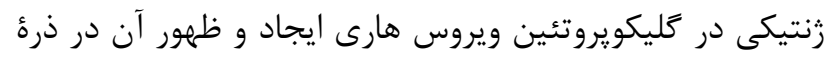

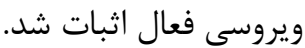

\section{روش : بثروهش}

\section{طراحى و ساخت گليكويروتئين جهشيافته}

ابتدا توالى زنتيكى كليكويروتئين ويروس هارى سويه پاستور

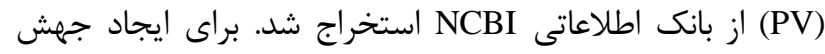

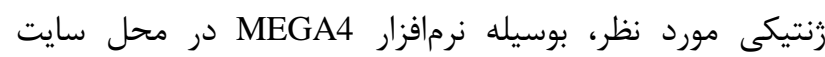

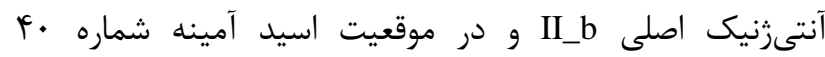
كليكويروتئين، تغيير كد زنتيكى كلايسين (GGG) به كد زنتيكي كلوتاميك اسيد (GAG) طراحى شد. توالى زنتيكى كليكويروتئين

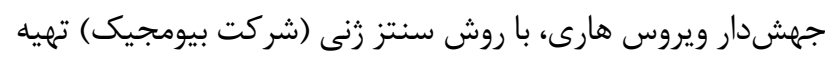

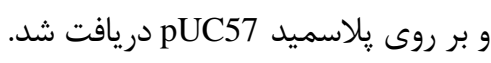

\section{وارد نمودن كَليكويروتئين جهشيافته در وكتور بيانى}

يلاسميد حامل گليكويروتئين جهش دار ويروس هارى بوسيله آنزيمهاى محدودالاثر SnaB I و Nco I شركت Shermo Fisher)

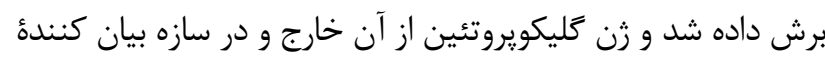

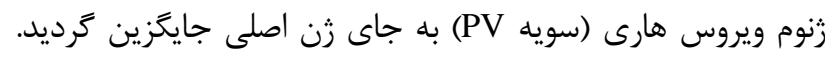

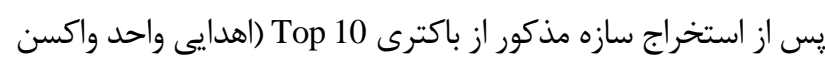

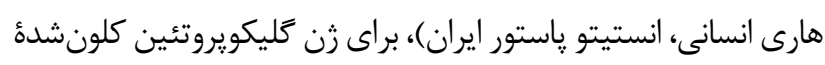

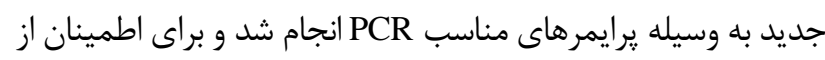

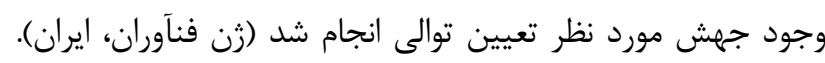

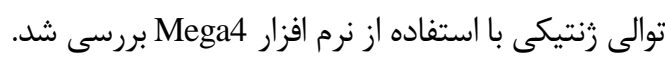

\section{كشت سلولهاى جانورى}

BSR (Baby تكثير و تعيين عيار ويروس هارى بر روى سلول Syrian Related)

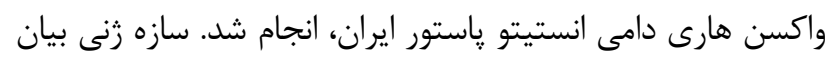

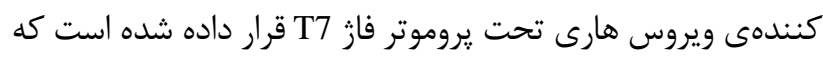

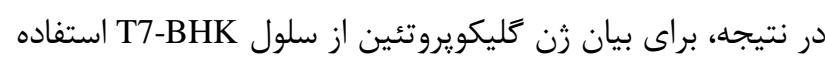

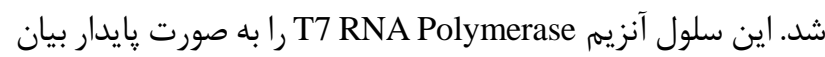
مى كند. سلول مذكور از بخش بانك سلولى انستيتو ياستور ايران

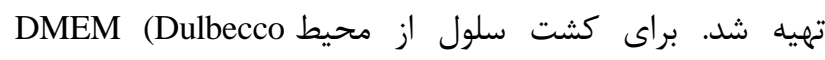
بهمراه (1\% سرم جنين گوساله 


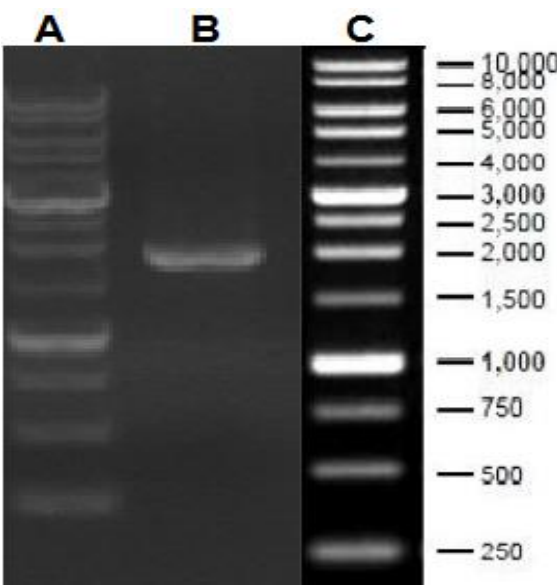

شكل r. نتيجه PCR بر روى زن گليكويروتئين جهشيافته، يس از كلون

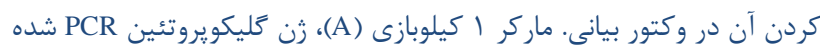
(B) (B)، الكوى ماركر وزنى استفاده شده.

ترانسفكشن سلول T7-BHK براى بيان سازههاى حاوى ثن

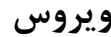

بيان زنها در سازههاى بيانى زن ويروس، بريائ بروموتر آنزيم

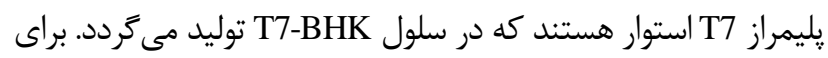
اطمينان از صحت عملكرداين سلول در بيان يليمراز ذكر شده، سلولها

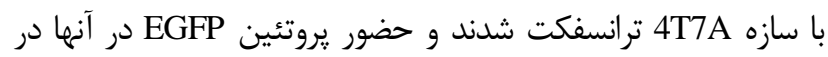

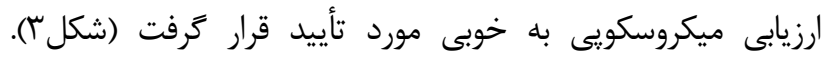
ترانسفكشن سلول مذكور با سازهاى زنومى و سازههاى بيان كنندهُ زن

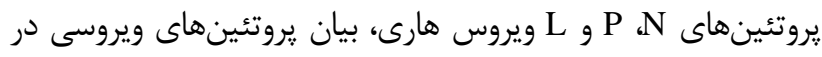

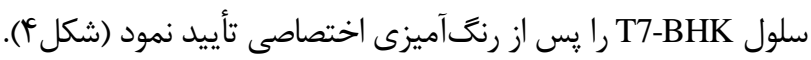

\section{تأييد توالى ويروس جهش يافته بس از بازيابى}

به منظور مقايسه توالى ويروس جهشيافته با ساير نمونههاى

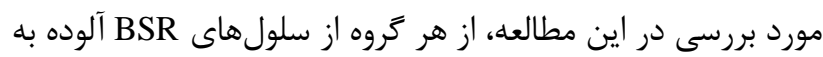

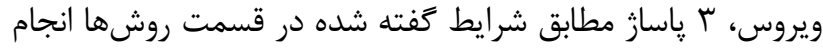
شد. در مرحله بعد سلولها جمعآورى شدند و از آنها استخراج

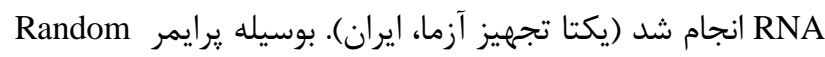

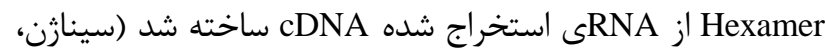

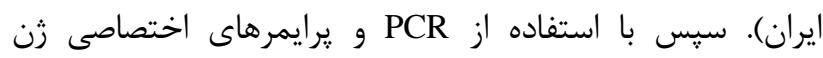

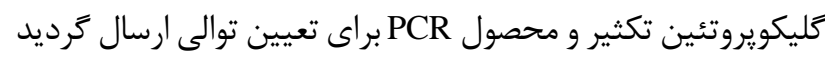
(زيست فناورى بيشعام، ايران).

\section{يافته ها}

\section{تأييد توالى زن كَليكويروتئين جهش يافته در وكتور بيانى}

باكمك برش دو انتهاى زن كليكويروتئين هارى داراى جهش،

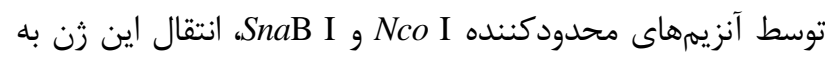
داخل سازه بيان كنندهُ زنوم ويروس هارى (سويه PV) انجام شد. از

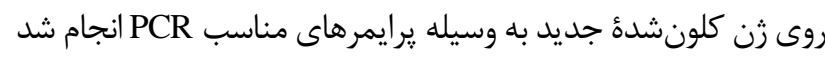

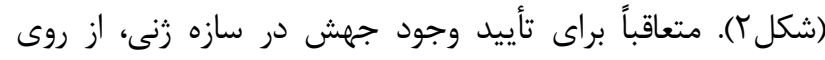
محصول PCR تعيين توالى صورت كرفت و بررسى توالى، جايكزينى اسيدآمينه كلايسين با كلوتاميك اسيد را تأييد نمود.
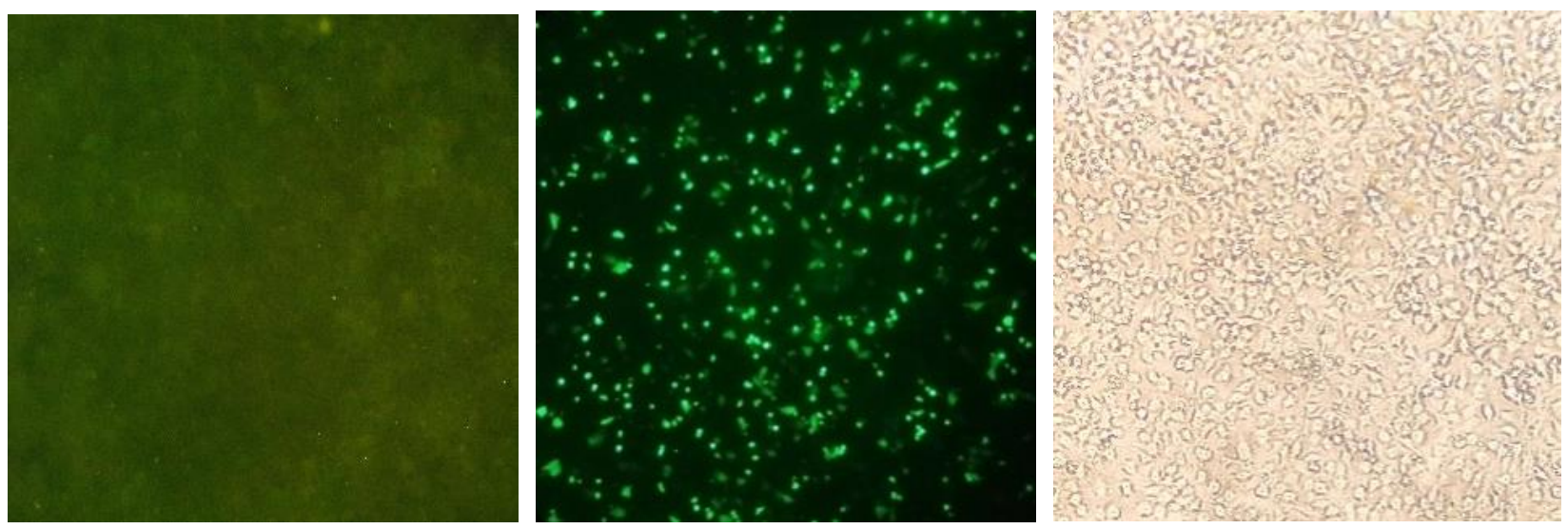

شكل س. نتايج ترانسفكشن سلول T7BHK سلول T7BHK (راست)، سلول T7BHK ترانسفكت شده با سازه 4T7A براى تأييد عملكرد يليمراز T7 (وسط)، همان

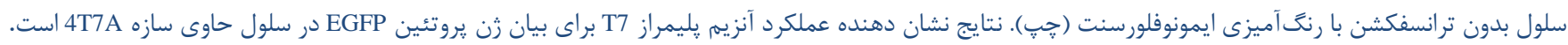



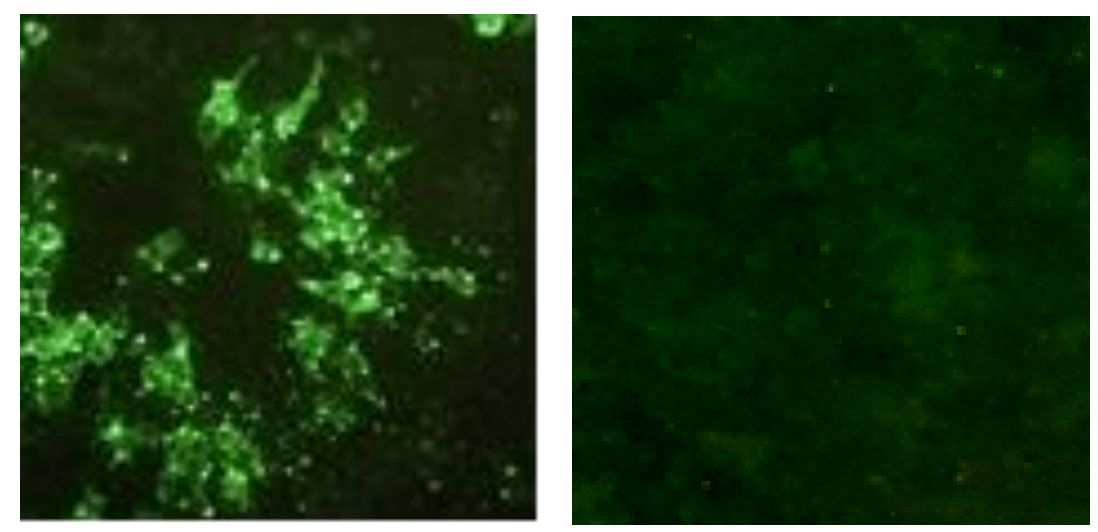

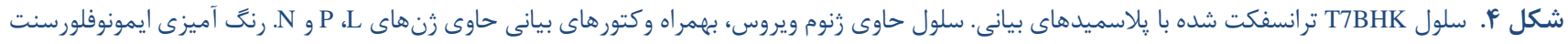

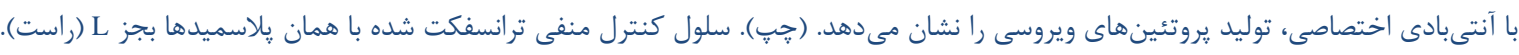

اختصاصى اين موضوع را تأييد كرد. همجنين مشاهده شد كه توان

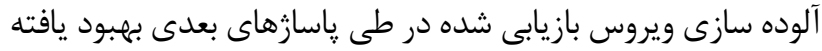

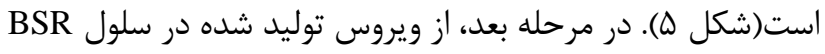

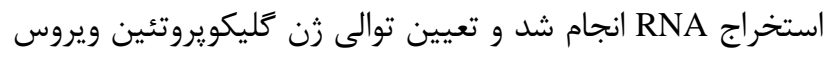
وجود جهش در ويروس بازيابى شده را تأييد نمود (شكل ؤن كليكورين.

\section{عفونتزايى ويروسهاى بازيابى شده در سلول BSR} نتايج مجاور نمودن سلولهاى BSR با محيط كشت حاوى ويروسهاى بازيابى شده در مرحله قبل نشان داد كه محيط كشت نهاي

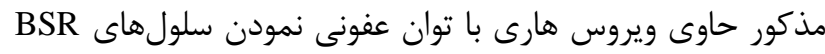

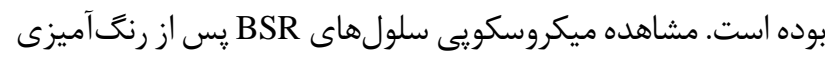
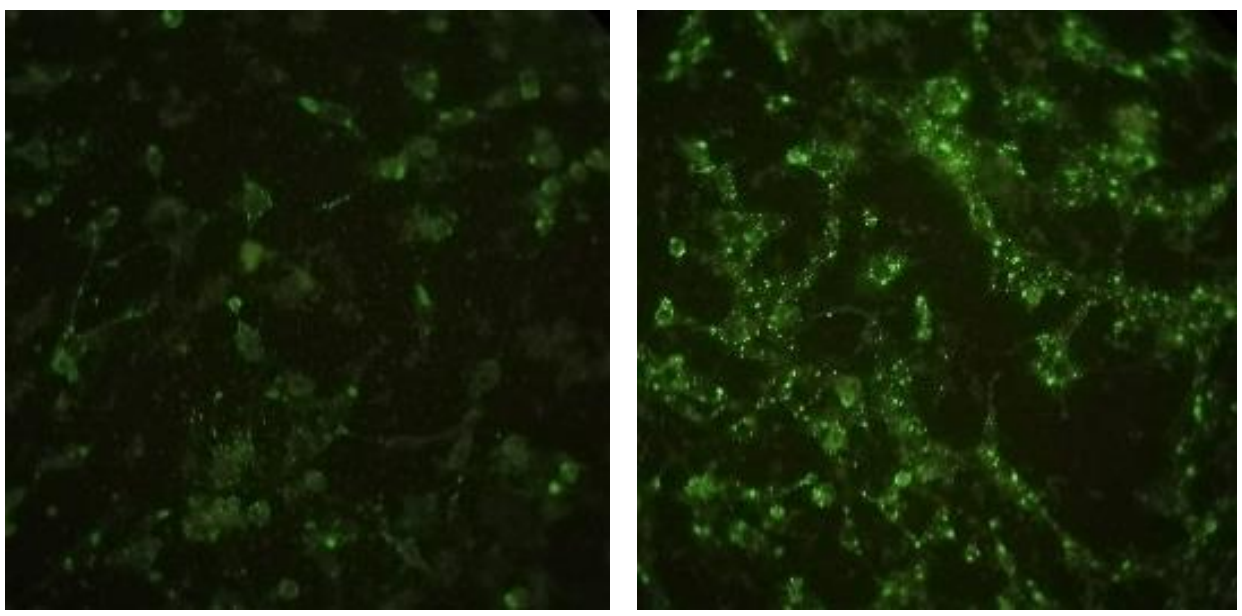

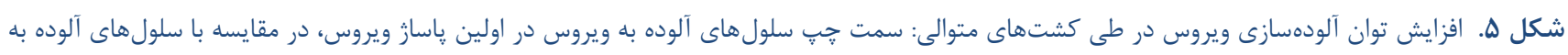
ياساز دوم ويروس (سمت راست) را نشان مى دهد.

\begin{tabular}{l|l|l}
\hline DNA Sequences & Translated Protein Sequences
\end{tabular}

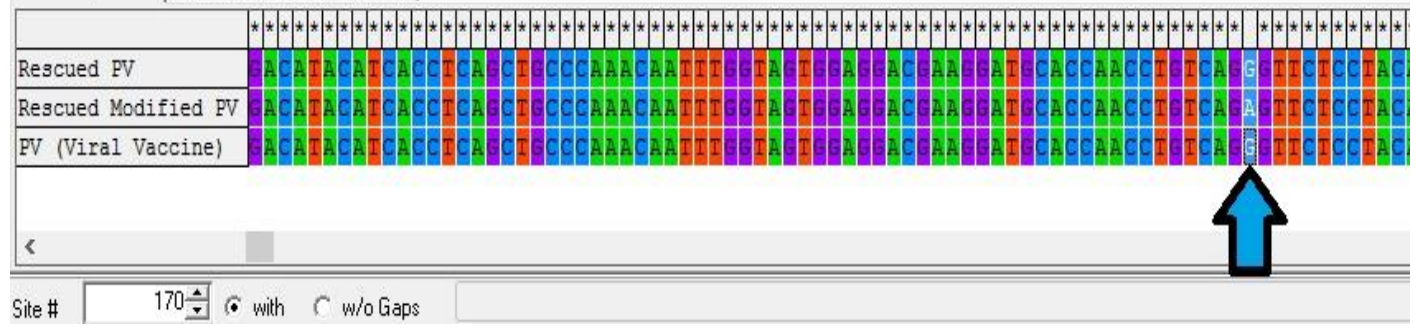

شكل צ. تعيين توالى گليكويروتئين ويروس بازيابى شده بدون جهش (Rescued PV)، ويروس سويه واكسينال شاهد (PV)، ويروس بازيابى شده جهش يافته (Rescued Modified PV) 
جايكاه II آنتىرنى كليكويروتئين ويروسى را تعيين خصوصيت

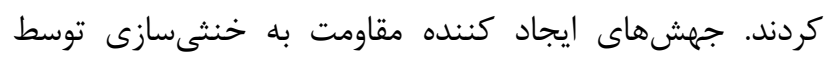

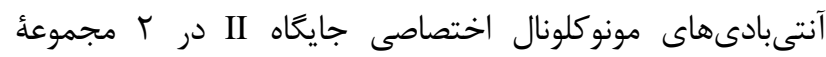

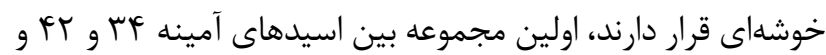

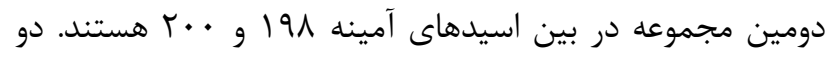

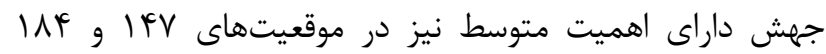

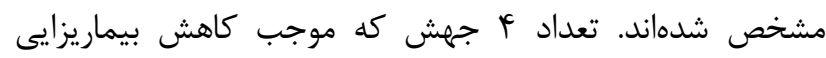
ويروس در موشهاى بزر كسال مىشد نيز شناخته شدند(19). جهش

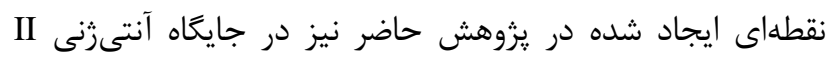

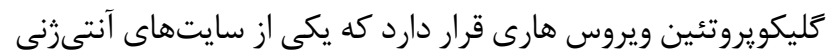

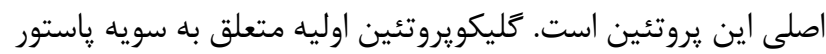

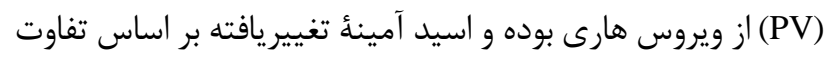

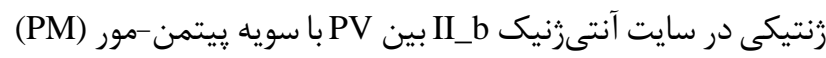
انتخاب شد. هر دو اين سويههاى ويروسى در ساخت واكسن هارى

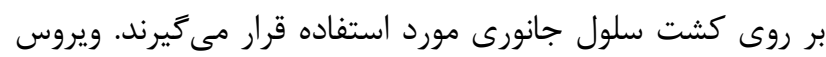

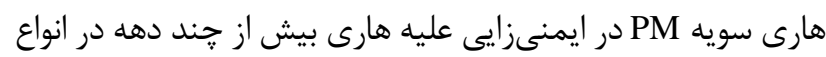
واكسنهاى ضد هارى در انسان با موفقيت مورد استفاده قرار گرفته

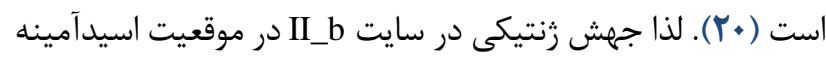

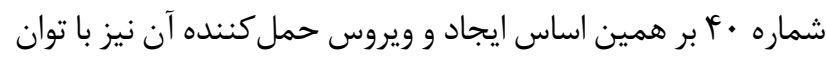
تكثير در كشت سلول جانورى بدست آمده است. ايجاد تغييرات

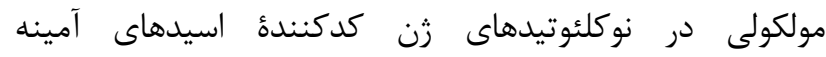

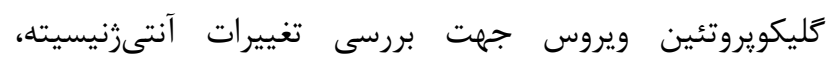

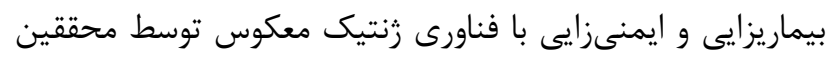

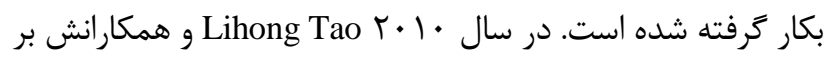

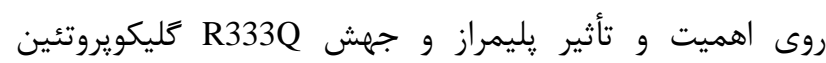

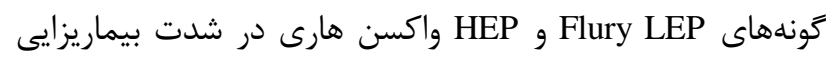

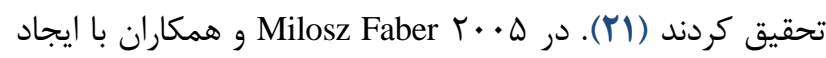

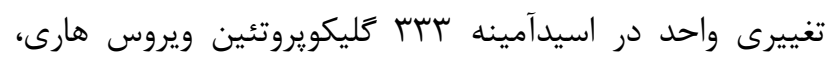

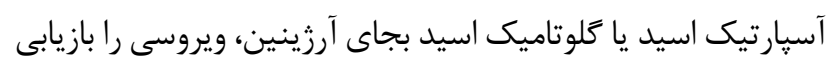

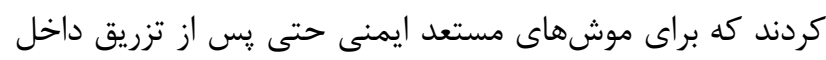

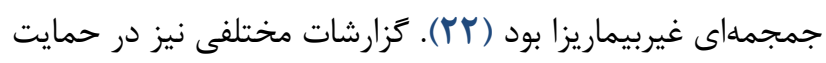

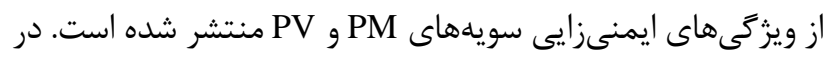

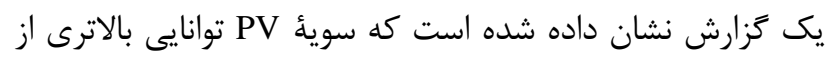

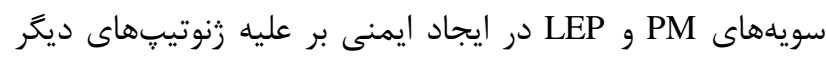

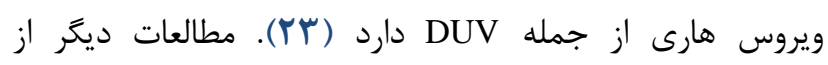

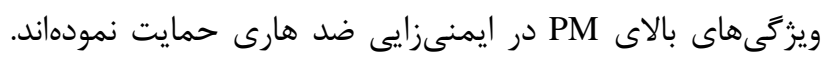

در اين يزوهش، با استفاده از روشهاى مهندسى رنتيك، تغيير

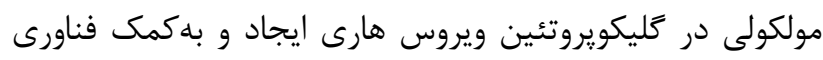
رنتيك معكوس ويروس نوتركيب حاوى اين كليكويروتئين بازيابى شد. ويروس بدست آمده توانايى عفونتزايى در كشت سلول جاني جانورى

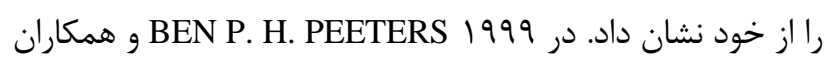
از سيستم زنتيك معكوس براى بازيابى ويروس نيوكاسل طبق داد دان

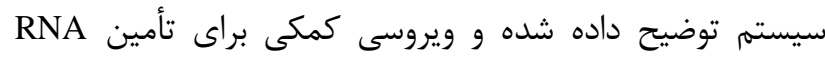

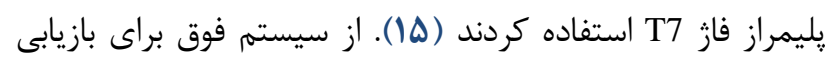

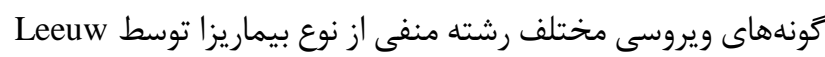

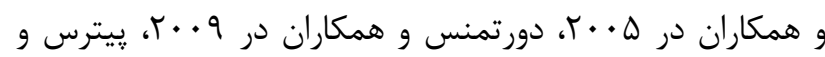
همكاران در 1999 بطور كارآمد استفاده شده است (9) دمان. در سال

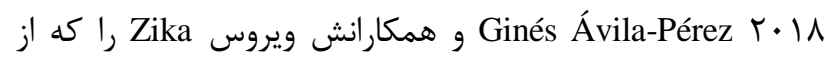

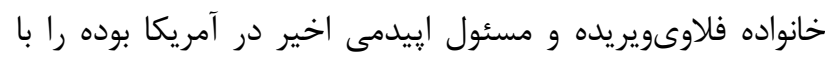

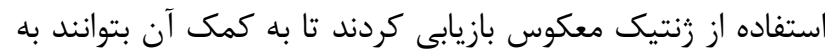
برخى از سوالات در مورد بيولوزى ويروس زيكا ياسخ بدهند و

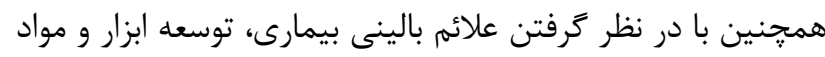

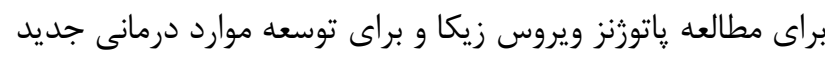

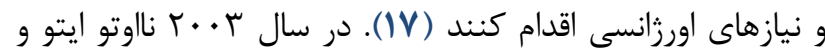

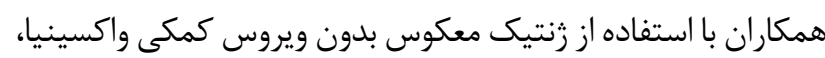

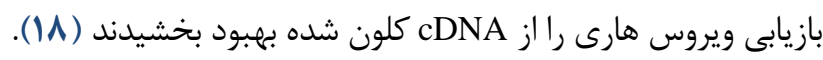

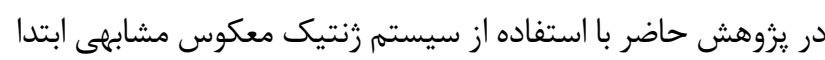

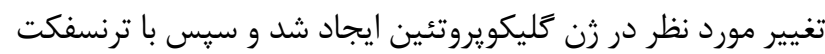

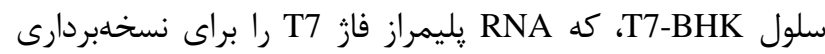

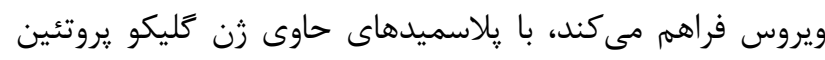

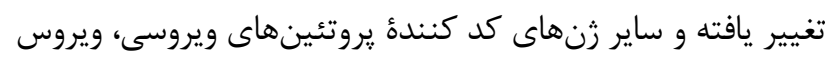

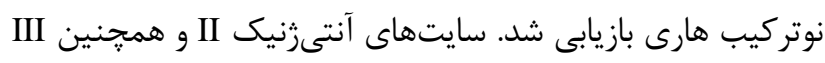

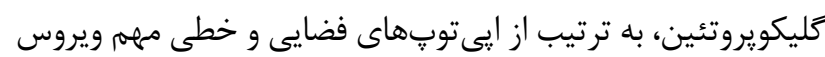

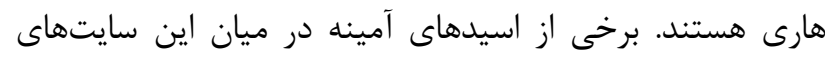

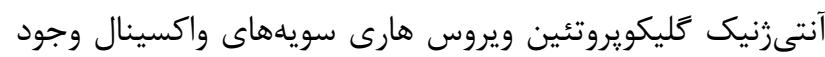
دارند كه در بين سويههاى مختلف ويروس هارى بسيار حفظ شده

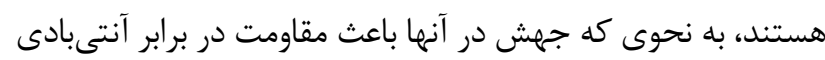

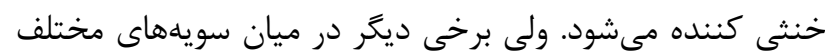

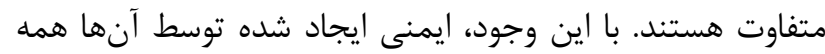

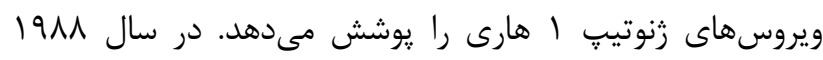
Christophe Prehaud

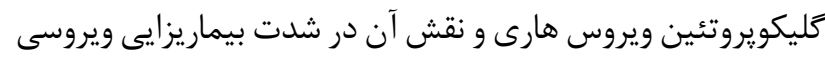

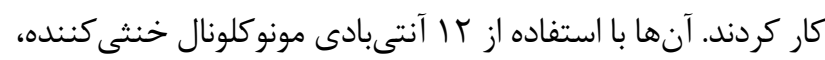


اساسى دارد كه عبارتند از () مشاركت جامعه، r) آموزش، آكاهى

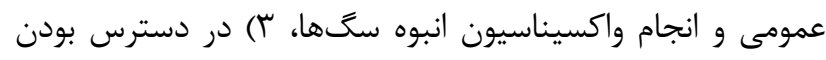

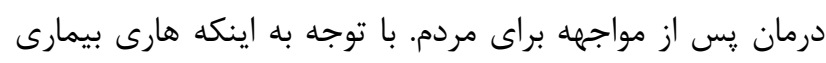

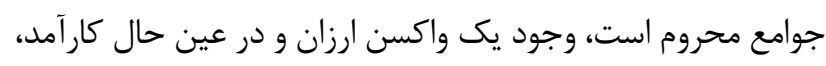

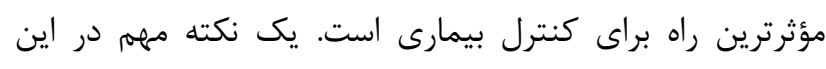
خصوص اين است كه، ملاك اصلى درتعيين ايمنىزايى واكسن هاى

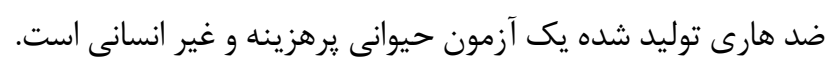

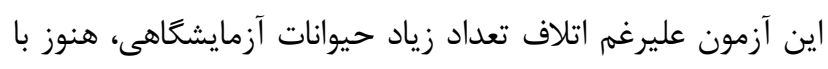

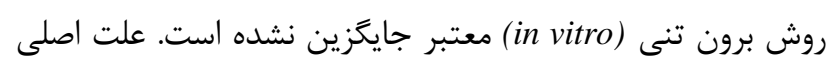

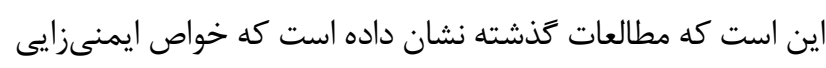

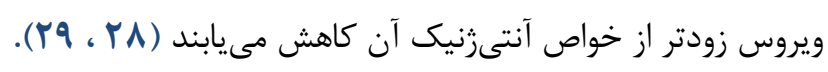

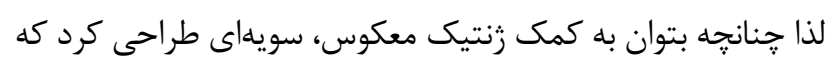

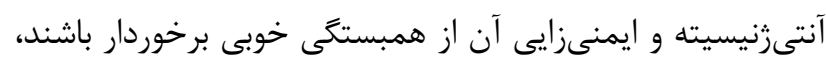

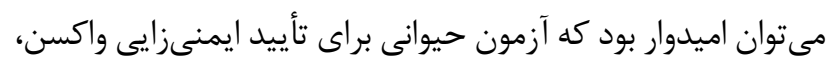

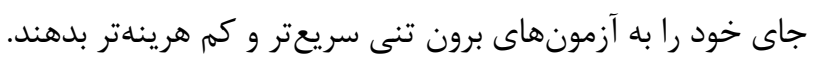

$$
\text { نتيجه } \bar{~}
$$

در اين يزوهش سعى شده با ايجاد تغيير در ساختار يروتئين

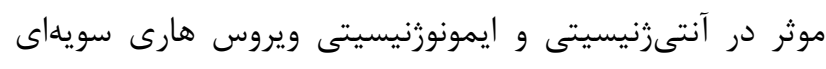

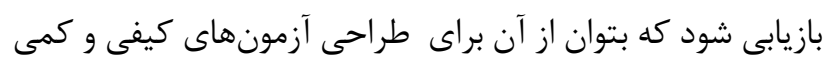
مورد نياز واكسن هارى استفاده كرد.

\section{سياسگز ارى}

بدينوسيله، از تمامى اشخاصى كه با ارائه نظرات ارزشمند،

$$
\text { ما را يارى كردند قدردانى مى كنيم. }
$$

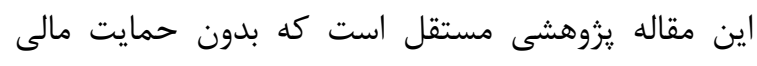

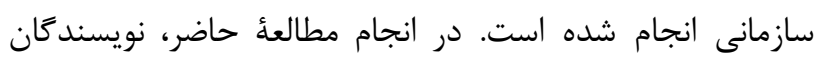
هيج كونه تضاد منافعى نداشتهاند.

\section{Referance}

1. Sudhi Ranjan Garg, Rabies in Man and Animals, Springer India, 2014.

2. Rabies - epidemiology, pathogenesis, public health concerns and advances in diagnosis and control: a comprehensive review. Veterinary quarterly, 2017 VOL.
37 ,
NO.
1 ,
212-251

[DOI:10.1080/01652176.2017.1343516] [PMID]
تحقيقات نشان داده كه آنتىبادىهاى تك دودمانى بر:ائً

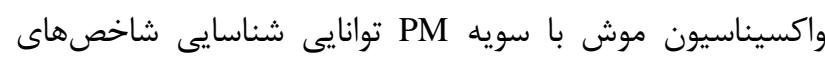

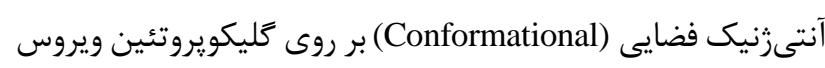

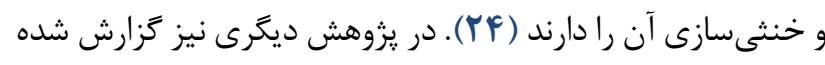

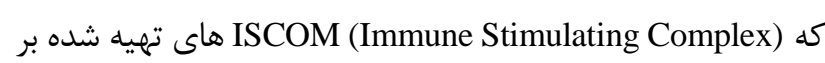
يائُ سويههاى PM و PVS ايمنى كافى در مقابل دوزهاى كشنده

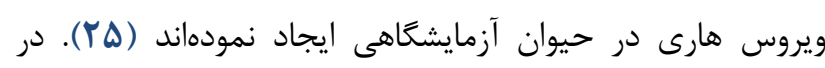

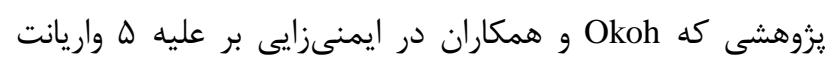

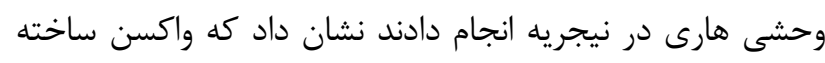

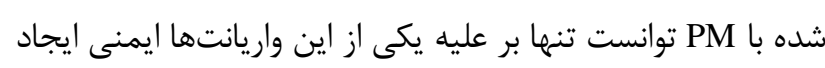

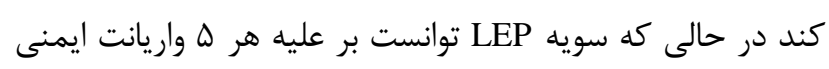

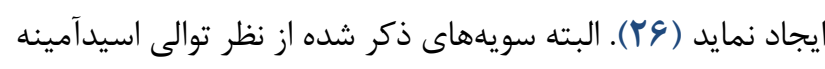

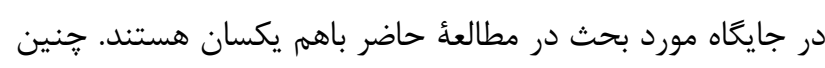

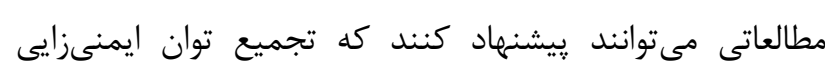

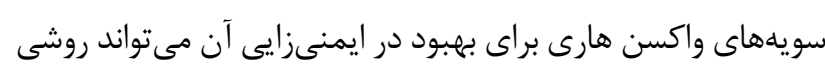

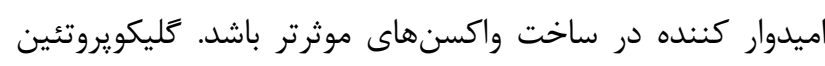

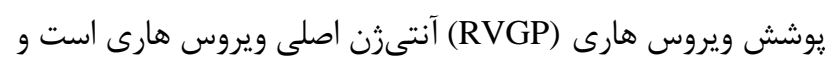

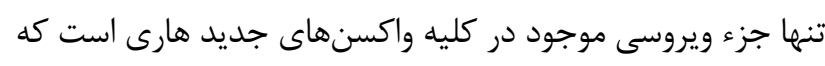

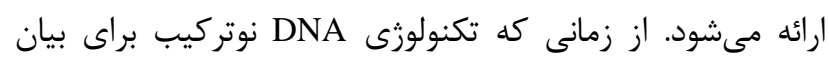

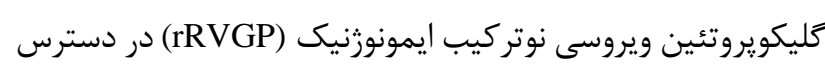

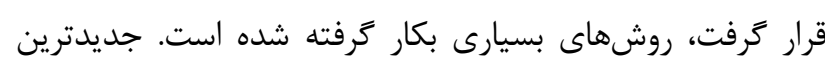

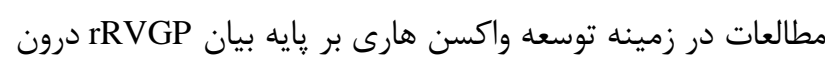

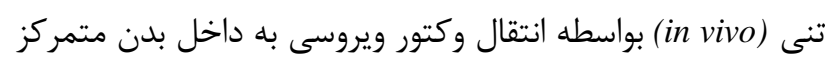

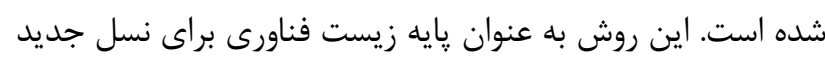

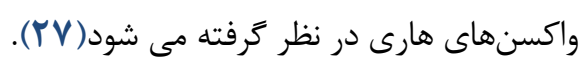

با در نظر گرفتن بى خطرى سويههاى ويروسى مبدأ و مقصد

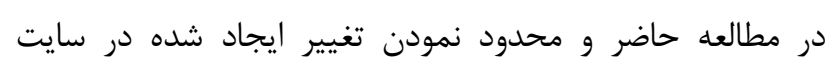

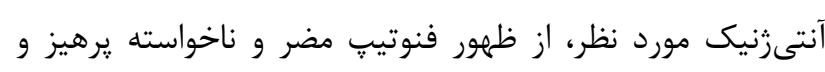

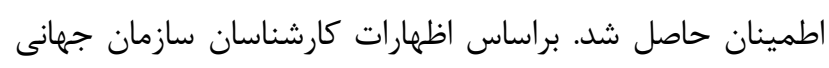

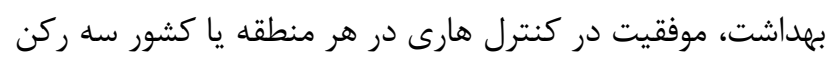

3. Kuzmina et al., Conservation of Binding Epitopes for Monoclonal Antibodies on the Rabies Virus Glycoprotein. J Antivir Antiretrovir 2013, 5:2. [DOI:10.4172/jaa.1000061]

4. Lihong Tao et al., Molecular Basis of Neurovirulence of Flury Rabies Virus Vaccine Strains: Importance of the Polymerase and the Glycoprotein R333Q Mutation. 
Journal of Virology. 2010, 9; 84, (17):8926-8936 [DOI:10.1128/JVI.00787-10] [PMID] [PMCID]

5. Le Blanc et al, Endosome-to-cytosol transport of viral nucleocapsids. Nature Cell Biology, (2005). 7(7), 653664. [DOI:10.1038/ncb1269] [PMID] [PMCID]

6. Andrés Ross B. et al, Rabies virus glycoprotein: structure, immunogenicity and role in pathogenesis. Rev Chil Infect. 2008; 25 (Suppl):S 14-S 18

7. Kibruyesfa Bayou, Current Techniques and Applications of Reverse Genetics: An overview. International Journal of Genetics. 2017, 7(2): 31-37.

8. Christopher C. Stobart and Martin L. Moore. RNA virus Reverse Genetics and Vaccine Design. Review, Viruses 2014, 6: 2531-2550. [DOI:10.3390/v6072531] [PMID] [PMCID]

9. Radecke F, Spielhofer P, et al. Rescue of measles viruses from cloned DNA. EMBO J. 1995; 14(23):5773-84. [DOI:10.1002/j.1460-2075.1995.tb00266.x] [PMID] [PMCID]

10. Taniguchi T, Palmieri M, Weissmann C. Q $\beta$ DNAcontaining hybrid plasmids giving rise to $\mathrm{Q} \beta$ phage formation in the bacterial host. Nature. 1978; 274:223-8. [DOI:10.1038/274223a0] [PMID]

11. Luytjes W, Krystal M, Enami M, Parvin J, Palese P. Amplification, expression, and packaging of a foreign gene by influenza virus. Cell. 1989; 59:1107-13. [DOI:10.1016/0092-8674(89)90766-6]

12. Ghaderi M, Sabahi F, Sadeghizadeh M, Khanlari Z, Jamaati A, Nasab SDM, et al. Construction of a Minigenome Rescue System for Measles Virus, AIK-c Strain. Iran J Biotech. 2014; 12(2):e18002. [DOI:10.5812/ijb.18002]

13. Ajorloo M., Bamdad T., Gholami A., Azadmanesh K. Assessment the efficiency of the constructed minigenome of rabies virus using PV strain as helper virus. Arch Iran Med. 2016; 19(5):335 - 41.

14. Mostafa Ghaderi, et al,Construction of an eGFP Expression Plasmid under Control of T7 Promoter and IRES Sequence for Assay of T7 RNA Polymerase Activity in Mammalian Cell Lines. Iranian Journal of Cancer Prevention, 2014; 3:137-41.

15. Ben P. H. Peeters, Olav S. de Leeuw, Guus Koch, Arno L. J. Gielkens. Rescue of Newcastle Disease Virus from Cloned cDNA: Evidence that Cleavability of the Fusion Protein Is a Major Determinant for Virulence. 1999, JOURNAL OF VIROLOGY, June, p. 5001-5009. [DOI:10.1128/JVI.73.6.5001-5009.1999] [PMID] [PMCID]

16. Ben Peeters, Olav de Leeuw, A single-plasmid reverse genetics system for the rescue of non-segmented negativestrand RNA viruses from cloned full-length cDNA, Journal of Virological Methods 248 (2017) 187-190. [DOI:10.1016/j.jviromet.2017.07.008] [PMID]
17. Ginés Ávila-Pérez, Aitor Nogales, Verónica Martín, Fernando Almazán and Luis Martínez-Sobrido, Reverse Genetic Approaches for the Generation of Recombinant Zika Virus. 2018, Viruses, 10, 597. [DOI:10.3390/v10110597] [PMID] [PMCID]

18. Naoto Ito, Mutsuyo Takayama-Ito, Kentaro Yamada, Junji Hosokawa, Makoto Sugiyama, and Nobuyuki Minamoto, Improved Recovery of Rabies Virus from Cloned cDNA Using a Vaccinia Virus-Free Reverse Genetics System. 2003, Microbiol. Immunol. 47(8), 613617. [DOI:10.1111/j.1348-0421.2003.tb03424.x] [PMID]

19. Prehaud C, Coulon P, Lafay F, Thiers C, Flamand A. Antigenic site II of the rabies virus glycoprotein: structure and role in viral virulence. J Virology. 1988, 1;62(1):1-7. [DOI:10.1128/JVI.62.1.1-7.1988] [PMID] [PMCID]

20. Fletcher MA. Hessel L., Plotkin SA. Human diploid cell strains (HDCS) viral vaccines. Dev Biol Stand. 1998; 93:97-107.

21. Milosz Faber, Marie-Luise Faber, Amy Papaneri, and et al. A Single Amino Acid Change in Rabies Virus Glycoprotein Increases Virus Spread and Enhances Virus Pathogenicity. 2005, JOURNAL OF VIROLOGY, Nov., p. 14141-14148. [DOI:10.1128/JVI.79.22.1414114148.2005] [PMID] [PMCID]

22. Milosz Faber, Marie-Luise Faber, Amy Papaneri, and et al. A Single Amino Acid Change in Rabies Virus Glycoprotein Increases Virus Spread and Enhances Virus Pathogenicity. 2005, JOURNAL OF VIROLOGY, Nov., p. 14141-14148. [DOI:10.1128/JVI.79.22.14141$\underline{14148.2005]}$ [PMID] [PMCID]

23. Lafon M (1), Bourhy H, Sureau P. Immunity against the European bat rabies (Duvenhage) virus induced by rabies vaccines: an experimental study in mice. Vaccine. 1988 Aug; 6(4): 362-8. [DOI:10.1016/0264-410X(88)90184-3]

24. Bunschoten H(1), Gore M, Claassen IJ, Uytdehaag FG, Dietzschold B, Wunner WH, Osterhaus AD. Characterization of a new virus-neutralizing epitope that denotes a sequential determinant on the rabies virus glycoprotein. J Gen Virol. 1989 Feb; 70 (Pt 2):291-8. [DOI:10.1099/0022-1317-70-2-291] [PMID]

25. Fekadu M, Shaddock JH, Ekström J, Osterhaus A, Sanderlin DW, Sundquist B, Morein B. An immune stimulating complex (ISCOM) subunit rabies vaccine protects dogs and mice against street rabies challenge. Vaccine. 1992; 10(3):192-7. [DOI:10.1016/0264410X(92)90011-8]

26. Okoh AE, Umoh JU, Ezeokoli CD, Addo PB. Vaccination challenge studies with variants of street rabies virus isolated in Nigeria. Vaccine. 1988 Feb; 6(1): 19-24. [DOI:10.1016/0264-410X(88)90008-4]

27. Renato Mancini Astray, Soraia Attie Calil Jorge, Carlos Augusto Pereira. Rabies vaccine development by expression of recombinant viral glycoprotein. 2016, Arch Virol. 
28. Mayner RE, Needy CF. Evaluation of the single radialimmunodiffusion assay for measuring the glycoprotein content of rabies vaccines. J Biol Stand. 1987 Jan; 15(1):110. [DOI:10.1016/0092-1157(87)90011-4]

29. Lyng J, Bentzon MW, Ferguson M, Fitzgerald EA. Rabies vaccine standardization: International Collaborative Study for the Characterization of the fifth International Standard for Rabies Vaccine. Biologicals. 1992 Dec; 20(4): 301-13. [DOI:10.1016/S1045-1056(05)80051-X] 